\title{
Bob Dylan: Poet of Disruption, Dissonance and an Aesthetic of Dissent
}

\author{
Shobana Mathews \\ Christ University, Bangalore. ORCID oooo-0oo1-9700-9420. \\ Email: shobhana.p.mathews@christuniversity.in
}

Received February 27, 2017; Revised on June 10, Accepted June 12, 2017; Published June 15, 2017.

\begin{abstract}
This paper is a brief study of the pivotal figure of folk rock, Bob Dylan. Acclaimed as a songwriter and singer, he was also the poetic voice of the counter culture of the nineteen sixties in America. The counter culture sought to unseat the mainstream establishment that seemed obsessed with war, conservative ideals and religious nationalism. Dylan burst onto this scene 'already a legend' and 'the unwashed phenomenon' (Baez, 1975) projecting the image of the original vagabond and troubadour. A glance at a selection of some of his best known lyrics disabuses one of the notions of his being uninitiated into the discourse of philosophy and literature. He draws freely on and engages with ideas from texts that are sometimes even obscure. The Nobel he was awarded in October 2016 recognized his art for evolving new modes of poetic expression. This paper studies Dylan, the performer and the writer who has masterfully disrupted most accepted literary modes using the dissonance-rich space of Rock music while retaining some of the traditional forms of poetic utterance.
\end{abstract}

Keywords: Dissonance, disruption, aesthetic of dissent, folk song, protest, rock and roll, Bob Dylan

\section{'The Unwashed phenomenon' - Bob Dylan: Voice of the Counter Culture}

Critical thought amongst academia remains polarized about Bob Dylan winning the Nobel Prize for literature. Strangely, it took a figure hitherto relegated to the phenomena of popular culture to make the academic community actually assess and redefine definitions of poetry, literature, the relevance of art and the role of the artist in today's troubled times. While it is almost unanimously accepted that Dylan is a songwriter of critical note the question lingers as to whether that justified his victory over many other writers of literary acclaim (Philip Roth and Murakami being among the contenders).

Well, comparisons are odious but prizes are always about competition. What then was Dylan's unique claim to fame in this august company?

While the wandering minstrel or troubadour, cradling a lyre, has been a figure who haunts the memory of literature, the transition to a guitar and harmonica therefore cannot be a matter of great concern. The musicality of literature, poetry in particular has never been questioned but the poetry of music, particularly pop music and the rather distant echoes of the American Folk Rock genre is a matter of intrigue. Or even suspicion.

(c) AesthetixMS 2016. This Open Access article is published under a Creative Commons Attribution Non-Commercial 4.0 International License (http://creativecommons.org/licenses/by-nc/4.o/), which permits non-commercial re-use, distribution, and reproduction in any medium, provided the original work is properly cited. For citation use the DOI. For commercial re-use, contact editor@rupkatha.com 
So Dylan with his carefully disheveled hair, crumpled clothes, rasping, nasal voice by turn gravelly and tender and his predilection for the musical instruments of mass appeal, the guitar, electric and acoustic and the harmonica, then stands out in our imagination as an agent of disruption.

Interestingly, Rock as a popular music genre, though it is so hard to define, has at its heart, dissonance. To posit a definition of Rock might seem futile, but by negation it is less formidable a task. For instance, bands like Pink Floyd have defied the radio air time norms of 3 minute long songs with refrains that are easily memorized at regular intervals that set one's foot tapping to rhythms meant for the dance floor. Rock therefore is not restrained by recording industry norms; it is irregular in terms of composition and often echoes dissatisfaction with the establishment, earning its proud epithet of 'anti establishment'.

Given the scope of Rock to define itself through rejection and non conformism, it also becomes the ideal mode for protest and the voice of the counter culture.

A singer, burdened as he was with the angst of social injustice, Dylan observed, "what's wrong goes much deeper than the bomb. What's wrong is how few people are free" (Cott, 1985).

Coming of age in an era as volatile as the nineteen sixties in America, Dylan was quickly hailed as their favourite poet by college students and journalists alike. However, poets like W $\mathrm{H}$ Auden lamented that they did not know his work at all and that there were too many things to be read, anyway. Scholars were unfamiliar with the vox populi.

The generation that hailed Dylan as their prophet and seer was also one of great faith and given to some of the worst follies. While the American establishment upheld conservative Christian and traditional values such as rationalism, technology, organization, control and temperance, the counter culture responded with eastern mysticism, studied disorganization, self indulgence and when it came to politics, radicalism or abstention.

What the mainstream tried to conceal, ignore, refine or purge away from human experience the counter culture delighted in exploring openly and tauntingly: noise, sex, homosexuality, speed, psychopaths, the grotesque and death.

While protesting a great many things the biggest and loudest 'no' the sixties said was to stasis, finding an anthem in songs such as Like a Rolling Stone, which extols the virtues of movement and exploration and celebrates the feeling of being 'on your own, like a complete unknown, with no direction home'. Reinventing the cliché of the rolling stone that gathers no moss, Dylan equates moss with the social baggage of class consciousness that keeps one fixed and stagnant and unexposed to the vicissitudes' of life in the raw, brutal and honest.

\section{A Generation of Unrest:}

From Freedom Riders protesting segregation in bus terminals by simply taking rides (1961), Martin Luther King Jr's moving speech in front of the Lincoln Memorial (1963) to the construction of resurrection City in Washington out of plywood planks by the Poor People's Campaign (1968) protesting poverty, dissent was at the heart of public discourse.

With the ascent of mass media like radio and television, song became once again a vehicle for political and social thought. Though he denied it, Dylan's songs were topical as just a glance at some titles will show: The Death of Emmet Till, Ballad of Hollis Brown, The Lonesome Death of Hattie Carroll, Hurricane etc. Poetry, of course, outlives journalism. 


\section{The Joker and the Thief: Dylan, the Songwriter and Performer}

Born Robert Zimmerman, in Duluth, Minnesota, of Jewish parentage, he moved with his family to Hibbing of which town he says:

"You can stand at one end of Hibbing on the main drag

An' see clear past the city limits on the other end.

Hibbing's a good ol' town

I ran away from it when I was 10, 12, 13, 15, 15 1/2, 17 and 18”. (Dylan, 1988)

Opinions range from the view that he named himself after the Welsh poet, Dylan Thomas to naming himself after his uncle, Dillon, a view held by one of his biographers, Robert Shelton ${ }^{\mathrm{i}}$... He himself told Jonathon Cott in 1978, "I didn't create Bob Dylan. Bob Dylan has always been there ...always was. Sometimes, your parents don't even know who you are. No one knows but you."

Cott compared Dylan to Hermes, Greek god of thieves and inventor of the lyre and the shepherd's pipe and the Lord of the roads both geographical and psychological. A suitable analogy indeed. Dylan like Shakespeare drew inspiration from events around him, people and causes in line with his notion of freedom or the infringement of it. He is mercurial like Hermes (whose Roman counterpart is indeed Mercury). A modern day troubadour or an 'out loud poet' (Sequeira, 1991).

Among the first known troubadours, Guillame IX of the eleventh Century was known as a trovatore bifronte - a poet with two faces, the trait of a performer. In Dylan's case the faces are many as he reinvents himself with each new phase. So many that he almost seems round.

J M Curtis in Rock Eras (1987) cites Francesco Marinetti the futurist who said of the modern poet ${ }^{\mathrm{ii}}$

"He will begin by brutally destroying the syntax of his speech ... breathlessly he will assault your nerves with visual, auditory, olfactory sensations, just as they come to him" (Curtis, 1978).

Marinetti could well have been describing Dylan's work. Songs like Subterranean Homesick Blues and Bob Dylan's $115^{\text {th }}$ Dream fit this description closely, bringing in a feel of the circus ring, staccato rhythms and are quite literally a breathless sensory assault on the reader.

One of his biographers, Jonathon Cott, read him the following passage that Dylan extolled as 'the most mind- blazing chronicle of human behavior'

From a thief you should learn:

1)To work at night; if one cannot gain what one wants in one night then to try again the next night; 3)to love one's co worker just as thieves love each other; to be willing to risk one's life for a little thing; 5)not to attach too much value to things even though one has risked one's life for them -just as a thief will resell a stolen article for a fraction of its real value; 6 ) to withstand all sorts of beatings and torture but to remain what you are ;and 7)to believe that your work is worthwhile and not be willing to change it. - Rabbi Dov Baer, the Maggid of Mezeritch (Cott, 1985).

It is these qualities and the various influences on him like James Dean, and Arthur Rimbaud that gave him the clarity to see through illusions, both his own and of those around 
him. As Dylan once said in New York on 31 October, 1964, “it's Halloween and, uh, I've got my Bob Dylan mask on.” Behind this mask he was free to assume any image he pleased.

\section{'Thought -dreams': The Poetry of Bob Dylan}

According to Wayne Hampton, Bob Dylan's concern seems to be with the romanticisation of freedom and the condemnation of the alienated life of social outcasts. A concern that is sustained by juxtaposing images of hoboes, outlaws, prophets and saints. His art changes, innovates and even rejuvenates both form and content. Yet through it all runs an unmistakable and inimitable quality that makes it Dylanesque. From that plaintive weary plea, biting sarcasm, weird mirth, surreal progression of images or the explosive combination of all, Dylan evolves an aesthetic of dissent. Himself an agent of disruption, his lyrics, as varied as they are, are shot through with an acute awareness of the corruption of the human condition, a disdain for dishonesty and facades and a joyful identification for the outcast and outlaw.

To categorize Dylan as a mere poet of protest would be doing him an injustice. He is the dreamer, the lover and the satirist. However even in these other moods he maintains his position of one who lives on the fringe of society, rejecting societal norms and embracing an honest struggle to live fully.

Though his topical ballads use an actual event as a podium to protest racism, militarism and inequality and anthems like "Blowin' in The Wind" carry the weight of years of oppression and question tiredly:

Racism and Social Injustice:

"How many years can some people exist

Before they're allowed to be free?"

War and violence:

"How many times must the cannon balls fly?

Before they're forever banned?"

Political apathy:

"How many times can a man turn his head?

Pretending he just doesn't see?"

Dylan's most prophetic song yet has to be "Bob Dylan's $115^{\text {th }}$ Dream", an irreverent, sardonic series of mishaps that beset him and his fellow explorer, Capt Arab (evokes Melville's Ahab and is a subtle acknowledgement of the US adventuring in the Middle East). We are taken on a breakneck chase through murky streets, the 'muttering retreats' of American consumerism. Just as he seeks to leave this nightmarish place, he sees three ships a - sailing towards him and wishes Columbus, good luck!

"I was riding on the Mayflower

When I thought I spied some land

I yelled for Captain Arab

"I think I'll call it America"

I said as we hit the land 
Captain Arab he started

Writing up some deeds

He said, "Let's set up a fort

And start buying the place with beads"

Where people carried signs around

Saying, "Ban the bums"

The man says, "Get out of here

I'll tear you limb from limb"

I said, "You know they refused Jesus, too"

He said, "You're not Him

Well, the last I heard of Arab

He was stuck on a whale

That was married to the deputy

Sheriff of the jail

But the funniest thing was

When I was leavin' the bay

I saw three ships a-sailin'

There were all heading my way

I asked the captain what his name was

And how come he didn't drive a truck

He said his name was Columbus

I just said, "Good luck"." (Dylan, 1988)

Amongst the most beautifully constructed and performed of his songs are 'Mr. Tambourine Man' and “It's Alright, Ma, I'm Only Bleeding”. 'Tambourine Man' employs a tune that capture the movement of one who is truly

“'disappearin' through the smoke rings of my mind

Down the foggy ruins of time, far past the frozen leaves,

The haunted, frightened trees, out to the windy beach

... Yes, to dance beneath the diamond sky with one hand waving free

Silhouetted by the sea, circled by the circus sands

With all memory and fate driven deep beneath the waves,

Let me forget about today until tomorrow.” (Dylan, 1988)

The particular genius of this song in the brilliant sense of slow lazy spiraling into oneself till both memory and fate collide and merge into a hazy state of being. The near perfect rhyming both internal and terminal as well as the musical arrangement, acoustic guitars and harmonica, fuses inseparably together till it is hard to tell which supplements the other, lyric or tune.

While almost everyone agrees that the song refers to a psychedelic trip, one must also consider the fact that Dylan invokes and surrenders entirely to the Tambourine man and his magic swirling ship, he's ready to go anywhere, his boot heels wait to go wandering. In his Hermes avatar, Dylan proposes that the highway or the road, a central figure in American literary imagination provides an escape from the thralls of society and into one's self. The Tambourine man is then a modern day Pied Piper leading us to our senses just as the senses surrenders to him. 
The road or highway to Dylan commemorates pathways of self discovery and a return to innocence, much like the river served Mark Twain's narratives. The road is also indicative of speed and movement so vital to escape the stagnation that results from conforming to society. Dylan echoes the sentiments of Cervantes who said "the road is always better than the inn."

Lionel Read expounds: "Those who settle for fame or fortune as the inn, and having arrived, call it quits, and miss the whole point of life. Realistically, there is no inn, no ultimate point of arrival. It is the road now and forever-finite man probing infinity, finding his way, endlessly. All that matters are the lessons learned along the way."

Read's wisdom sums up Dylan's philosophy. Dylan's mercurial life, ever changing identities, masks that he dons and discards indicate a continuous process of experimentation, a protest against stagnation.

The lyric that best exemplifies this sentiment is the jeering 'Like a Rolling Stone'. The rolling stone is a derogatory term used to describe the vagabond, the hobo, the tramp and the outlaw. These figures are also the beloved of counter cultures and fringe cultures. Diogenes of Sinope was one such person in ancient Greece He was the son of a banker but chose to live in the streets and fraternize with whores, stealing from temples, begging futilely from statues to learn rejection and finally being sold into slavery for forgery. He said iii "The people of Sinope condemned me to banishment, but I condemned them to be themselves and to remain where they were."

In the same vein, Dylan in this song mocks at the sheltered Miss Lonely who finds herself down and out and having to scrounge her next meal, which Dylan taunts her for.

"Now you don't talk so loud now you don't seem so proud

About having to be scrounging your next meal

How does it feel, how does it feel?

To be without a home

Like a complete unknown, like a rolling stone

Ah you've gone to the finest schools, alright Miss Lonely

But you know you only used to get juiced in it

Nobody's ever taught you how to live out on the street

And now you're gonna have to get used to it

You say you never compromise

With the mystery tramp, but now you realize

He's not selling any alibis.." (Dylan, 1988)

At the heart of this lyric is a familiar trope, that of a populist man democratizing a snobbish woman. There seems to be a blurring between compassion and anger. JM Curtis observes that Dylan uses a kind of rhyme scheme used by Browning: the mosaic rhyme. Browning uses this rhyme scheme in his 'Christmas Eve and Easter Day'- between us / genus, appetite/ clap it tight, affirm any/ Germany. In 'Like a Rolling Stone' Dylan writes - alibis/of his eyes, diplomat / Siamese cat, amused / he used, refuse / to lose.

This lyric also exemplifies another innovative quality of his art - the ability according to Christopher Ricks to 'rotate a cliché so that a facet of it catches a new light '(Ricks, 1995). Thus the derided rolling stone is reinvented and emerges as a counter culture hero... the complete unknown, with no direction home and therefore more free than most. 
'It's Alright, Ma' has a totally different tone, sardonic, frustrated and direct. The lyrics are aphoristic and he himself best describes the tone of this song in its own lyrics thus:

'Disillusioned words like bullets bark'.

The song has the steady yet staccato rhythm of the machine gun, assaulting our senses with a catalog of unnerving sensory data

"Old lady Judges watch people in pairs

Limited in sex, they dare

To push fake morals insult and stare

Whilst money doesn't talk, it swears

Obscenity, who really cares

Propaganda, all is phony" (Dylan, 1988)

He echoes the vitriol last seen in Alexander Pope's pen! There is a sense of resignation as he wryly observes, finally:

"And if my thought-dreams could be seen

They'd probably put my head in a guillotine

But it's alright, Ma, its life and life only". (Dylan, 1988)

Though his tone is world weary and resigned, one has faith in his untiring and unfailing ability to rise from the ashes of despair and to mount with wings of renewed vigor into realms of hope and of freedom, taking his listeners with him through the smoke rings of his mind.

\section{References}

[Recorded by J. Baez]. (1975). Diamonds \& Rust [Vinyl recording]. A \& M.

Bold, A. (1979). The ballad. London: Methuen.

Cott, J. (1985). Dylan. New York: Dolphin/ Doubleday \& Company Inc.

Curtis , J. M. (1987). Rock eras: interpretation of music and society, 1954-1984. Ohio: Bowling Green State University Popular Press.

Dylan, B. (1988). Lyrics, 1962-1985. London: Paladin.

Denisoff, R. S. (1991). Great day coming: Ann Arbor, MI: U-M-I Out-of-Print Books on Demand.

Denisoff, R. S. (1972). "Sing a song of social significance": political consciousness and the song of persuasion. Ohio: Bowling Green State University Popular Press.

Denisoff, R. S. (1975). Solid gold popular record industry. New Brunswick, New Jersey Transactions Inc Denisoff R.S. (1972). The sounds of social change studies in popular USA culture. Rand Mcnally \& Co.

A., D. T., \& Poulin, A. (1967). The American folk scene: dimensions of the folksong revival. New York: Dell Pub. Co.

Ewen, D. (1972). Great men of American popular song: the history of the American popular song told through the lives, careers, achievements, and personalities of its foremost composers and lyricists--from William Billings of the Revolutionary War through Bob Dylan, Johnny Cash, Burt Bacharach. Englewood Cliffs, NJ, New Jersey: Prentice-Hall.

Fisher, M. M., \& Billington, R. A. (2000). Negro slave songs in the United States. Place of publication not identified: Butler Press.

Forcucci, S. L. (1984). A folk song history of America: America through its songs. Englewood Cliffs, NJ: Prentice-Hall 
Marineti, F. (1913). Destruction of syntax-imagination without strings-words-in-freedom. Futurist manifestos, 98-104.

Hampton, W. (1986). Guerrilla minstrels. Knoxville: University of Tennessee Press.

Hamm, C. (1983). Music in the new world. New York: W.W. Norton and Company.

Heylin, C. (2011). Bob Dylan: behind the shades. London: Faber and Faber.

Hitchcock, H. W., \& Gann, K. (200o). Music in the United States: a historical introduction. Upper Saddle River, NJ, New Jersey: Prentice Hall.

Hoare, I. (1976). The soul book. New York: Dell.

Kingman, D. (1979). American: music a panorama . New York: Schirmer books.

Klonsky, M. (down in the village: a discourse 1971.). Down in The Village: A Discourse on Hip. New American Review, 13. New York: Simon and Schuster.

Mathews, S. (2016, October 15). The Joker and The Thief. The Hindu.

Mathews, S. (2016, October 18 ). A singing poet pushing boundaries. The Deccan Herald .

Pichaske, D. (1979). A Generation in motion, popular music and culture in the sixties. New York: Schirmer Books.

Read, L. (1993, June). Quoting cervantes. Readers Digest.

Ricks, C. (1995). The force of poetry . Oxford University Press.

Rodnitzky, J. L. (1976). Minstrels of the dawn: the folk-protest singer as a cultural hero. Chicago, IL: NelsonHall.

Seeger, P., \& Schwartz, J. M. (1993). The incompleat folksinger. Lincoln: Univ. Nebraska Press.

Sequiera, I. (1991). East and west: a study of popular culture. Delhi: B.R. Publishing Corporation.

Shelton, R. (1987). No direction home: the life and music of Bob Dylan. New York: Ballantine Books.

Shepard, S. ( 1977). Rolling thunder logbook. New York: Viking Press.

Tambling , J. (1990). What is Literary Language? Philadelphia: Open University Press.

Vassal, J., \& Barnett, P. (1976). Electric children: roots and branches of modern folkrock. New York: Taplinger.

Shobana Mathews did her MPhil on Bob Dylan in 1996, at Madras Christian College, Tambaram "Folksong As Poem: A Critical Study of the Lyrics of Protest Folksinger , Bob Dylan ". She is currently an Associate Professor in the Dept. of English, Christ University, Bangalore. She is pursuing her doctoral studies in the area of Spatiality, Sound and Aural Narratives focusing on a selection of the albums of Mark Knopfler. 